\title{
The Effectiveness of Make a Match Technique in Teaching Vocabulary
}

\author{
Ria Dhatun Nikmah \\ Department of English Applied Linguistic \\ Universitas Negeri Medan \\ Medan, Indonesia \\ riadhatunnikmah@gmail.com
}

\author{
Rahmad Husein \\ Universitas Negeri Medan \\ Medan, Indonesia
}

\author{
Busmin Gurning \\ Universitas Negeri Medan \\ Medan, Indonesia
}

\begin{abstract}
Make a match is a technique for teaching vocabulary. This study aimed at finding out the effectiveness of make a match technique in teaching vocabulary at eleventh grade of SMA MUHAMMADIYAH 2 Medan. This study is experimental design. The sample was consisted of 30 students. The data collection was done by administering pre test and post test in the form of objective test. In the data analysis, Paired sample $T$ Test was used to prove the hypothesis. Based on the data gained, it was found that the mean score of the pre test was 18.67 while the mean scores of the post test was 25.30 . It meant that there was a significant difference between pre test and post test, $t(d f=29)=19.282$ at $p=0.000$ that was lower than 0.05 . It means that the alternative hypothesis was accepted which indicates that make a match technique was significantly effective in the teaching vocabulary. Additionally, the result of this research shows that make a match technique is a goof vocabulary learning technique. It encourages greater self-direction for students. Thus, it is strongly suggested that teachers apply this technique to help improve vocabulary of the students.
\end{abstract}

Key words: make a match, teaching vocabulary, teaching technique

\section{INTRODUCTION}

Vocabulary is one of the important components of teaching English besides the other components such as structure, pronunciation and intonation. Vocabulary has a very important role. If a student is weak in vocabulary mastery, he cannot communicate his thought and ideas clearly as he wants both oral and written. He will not be able to read the text either that is a teaching material at school or existing in magazines, newspaper and so forth and also the ability in listening and reading will be constrained by limited vocabulary mastery. Already a common opinion, having sufficient vocabulary is a capital or a vehicle for smooth communication. Thus the students will not be able to communicate in the target language if his vocabulary mastery is inadequate.
The inability of most senior high school students to communicate in English one factor is due to lack of vocabulary mastery. The results of interviews on students on the preliminary study showed that all class XI students still have obstacles or have difficulty in mastering English vocabulary. The difficulty is related to memorizing, pronunciation of vocabulary, as well as in terms of vocabulary writing. Students assume that when reading a simple text in English, they are difficult to pronounce it so it is not easy to memorize the vocabulary in the sentence. Furthermore, when they succeed in remembering a vocabulary, they are also difficult to rewrite them. Usually in writing there will be an excess or lack of letters of a word that they write.

When students can master English vocabulary well, it will also be good students on the four existing skills. Therefore, vocabulary mastery will be very useful in conveying ideas. When reading a simple text in English, if the mastery of vocabulary students good, it will easily students can take the information contained in the text. When speaking and listening, if the vocabulary mastery of students good, then students can use their ability to communicate directly with tourists who also use the English. That way people who students know not only people who come from their own country, but from a foreign country. From the above explanation, it can be concluded that the vocabulary is closely related to the four language skills of reading, writing, listening and speaking.

Teacher should not only feel compelled to focus on vocabulary study so that students are exposed to rich, expressive language in which they can use variety of sentence structures, asks questions, make up stories talk enthusiastically about what they see and do. Therefore, effective learning techniques should be thought to provide students with successful vocabulary mastery.

Nowadays, a lot of things can be done by a teacher to improve the quality of vocabulary mastery of students. In this 
case, the researcher suggests using teaching techniques classroom. There are so many learning techniques that teachers can use. Teachers can also choose appropriate techniques on the material being taught. In this study, the technique that researcher will propose is Make a Match technique.

Curran (1994), emphasize that the basic principle of Make a Match is that the students find or match a partner while they are learning a concept or a particular topic in an interesting classroom atmosphere. Make a match is a form of learning by looking for a pair of cards that have been owned and done in pairs, then dealing with each other to explain the meaning of cards owned. One of the hallmarks of this technique is students looking for a partner while learning about a concept or topic in a fun atmosphere. based on the previous research, Dewi (2014) states that the using of Make a Match technique in teaching vocabulary is not only effective to lead students feel more interesting and enjoy doing activity, but also it can give the students opportunities to be active in learning English vocabulary.

Based on the background of the study, a study was conducted to see the effectiveness of Make a Match technique in teaching vocabulary at the eleventh grade of SMA MUHAMMADIYAH 2 Medan. Thus, two statements of problems are explored here. Those are:

1. Is Make a Match technique effective in teaching vocabulary at the eleven grade of SMA MUHAMMADIYAH 2 Medan?

2. How is the effectiveness of Make a Match technique in teaching vocabulary at the eleven grade of SMA MUHAMMADIYAH 2 Medan?

Based on the statement of the problem above, the purpose of this study was to know whether Make a Match technique was effective and how effective it was in teaching vocabulary at the eleventh grade student of SMA MUHAMMADIYAH 2 Medan.

The result of this study is expected to let teachers know the benefits of Make a Match for students' foreign language vocabulary development. By this, English teachers can have some concepts of how to teach and increase their students' vocabulary mastery. For more advance and deeper research, the result of this research is also expected to be a reference for those who are interested to conduct further investigation.

\section{LITERATURE REVIEW}

\section{Definition Make a Match}

Make a match was developed by Lorna Curran (1994). Make a match or find a partner is one of the alternatives that can be applied to students. Application of the technique starting from the students will look for a pair cards before deadlines.

Arifah and Kusumarasdyati (2013: 5) define Make a Match as one of the co-operative learning techniques that is used with pairs. The students are put into 2 groups, group A and group B. The number in each group depends on the number of cards prepared. Each student gets a card. Group A gets question (topic) cards; while group B gets the answer cards. When they have already found their matches, they can report it to the teacher.

The steps of Applying Make a Match

Aqib (2013:23) proposes procedures of make-a match technique. The steps are:

1. The teacher prepares some cards that contain some concepts or a suitable topic for review session, a part is contains questions and the other is the answer.

2. Every student gets a card.

3. Every student thinks the answer or the question from the card that they hold.

4. Every student finds their partner that has a matching card with his card.

5. Every student who finds their suitable card before the time up will get a point.

6. After the first session, the card is shuffled, so the students will get the different card in the next session. It is continued until this activity is ended.

7. Teacher together with the students make a conclusion from the material that have been given by teacher.

The Advantages of Make a Match

1. The students looking for the couple while learning about a concept or topic in a pleasant atmosphere.

2. Each student can be directly involved in answering a question given to them in the form of a card.

3. It can increase the students' creativity through matching the cards.

4. It can help avoid students being bored during the teaching-learning process.

5. Student cooperation will emerge dynamically

6. There is dynamic mutual help between the students

7. It can create a more interesting classroom atmosphere

The Disadvantages of Make a Match

1. Requires guidance from the teacher to conduct the activity

2. The time needed to be limited, students is not to let play too much in the learning process

3. Teachers need to prepare adequate materials and tools

4. Will create noise and crowds that are not controlled

In this learning technique students cannot develop their own creativity, and focus more on the teacher because the students only accept what is conveyed by the teacher, and the answer from the worksheet is not an analysis, so that students cannot dig deeper the existing material with this Make a Match learning technique. 
From the explanation of Make a Match learning model it can be concluded that the learning model of Make a Match is a development of lecture method but to know the students understanding about the material that has been submitted then given the worksheet in it contains the questions and answers contained in the word box. Require a carefulness and thoroughness in finding the right choice of answers. However, as with other learning models, the Make a Match learning model has flaws and advantages. The shortcomings of this learning model is that students receive only raw materials from teachers and cannot develop their creativity, because students are only required to seek answers not to develop the minds of their students. While the advantages of increasing accuracy, critical and effective thinking of students. Because students are required to find the most appropriate answer and must be observant in finding answers that exist in the worksheet.

\section{METHODOLOGY}

This study was conducted in SMA MUHAMMADIYAH 2 Medan in august 2018. In this study, the sample was chosen by using lottery technique. Not all of the population will be taken as the sample. Six classes were randomized and elected the class of eleventh 1 . This class will be sampled in this study. It will only 30 students which will divide into two groups and give a treatment by using a treatment by using Make a Match Technique.

In this research, pre experimental research in one group pre-test and post-test design is applied because this research had no control of extraneous variable. This research does not have random of subjects to groups. The one-group pre-test and post-test design usually involves three steps: (1) administering a pretest to measure a variable; (2) applying the experimental treatment $X$ to the subjects; and (3) administering a posttest, again measuring the variable. Differences attributed to application of the experimental treatment are then evaluated by comparing the pretest and posttest scores (Ary,2010, p.303). It is shown in Table I.

TABLE I. RESEARCH DESIGN: ONE GROUP PRETESTPOSTTEST DESIGN

\begin{tabular}{ccc}
\hline $\begin{array}{c}\text { pret } \\
\text { est }\end{array}$ & $\begin{array}{c}\text { Investigation } \\
\text { variable }\end{array}$ & $\begin{array}{c}\text { Postte } \\
\text { st }\end{array}$ \\
\hline $\mathrm{Y}_{1}$ & $\mathrm{X}$ & $\mathrm{Y}_{2}$ \\
\hline
\end{tabular}

Notes:

Y1 : Pre-test

$\mathrm{X}$ : Investigated variable; make a match technique in teaching vocabulary

Y2 : Post-test

This research consists of an investigated variable. The investigated variable of this research is vocabulary through make a match technique. The instrument used in this study is a test. The test is in form of multiple choice and matching meaning to measure students' vocabulary mastery. In this test,
30 items are provided: 25 items of multiple choices and 5 item of matching meaning. Every correct answer is given 1 score and each wrong answer is given 0 score.

In collecting data, a pre-test and post-test were administered. The pre-test was administered before doing the treatment, and the post-test was after doing the treatment through make a match technique. This aimed at knowing the students' governance on vocabulary after applying make a match technique.

\section{DISCUSSION}

Referring to the data gained, the standard deviation of the pretest was 2.279, and the standard deviation of the post-test was 1.179. Meanwhile, the mean scores in the pre-test and post-test were 18.67 and 25.30. The mean score after the technique was implemented was higher than the mean score before the treatment was implemented. It means that make a match technique was effective in teaching vocabulary. The scores are summarized in Table II.

TABLE II. SUMMARY OF FREQUENCY STATISTICS

\begin{tabular}{|c|c|c|c|}
\hline \multicolumn{3}{|c|}{ Pretest } & Posttest \\
\hline $\mathrm{N}$ & Valid & 30 & 30 \\
\hline Missing & & 0 & 0 \\
\hline Mean & & 18.67 & 25.30 \\
\hline Median & & 18.50 & 25.00 \\
\hline Mode & & $18 \mathrm{a}$ & 25 \\
\hline Std. & & 2.279 & 1.179 \\
\hline Deviation & & & \\
\hline Minimum & & 14 & 23 \\
\hline Maximum & & 25 & 28 \\
\hline Sum & & 560 & 759 \\
\hline
\end{tabular}

Vocabulary is an important ingredient of language, and vocabulary learning is an essential part of foreign language learning. Language learners need a wide array of words in a target language to be able to tackle both production and comprehension activities successfully in the foreign language. One way to help learners is by equipping them with variety of vocabulary learning strategies.

The finding in this research shows the advantages of make a match: increasing students' English vocabulary, helping students to strengthen their memory, training students to be patient in learning make a match, and training students to control their emotion. This theory is proven by the finding of the research.

Additionally, some previous research show that make a match is effective in teaching and learning vocabulary. The findings of the previous research are similar to the findings in this research which is that make a match is effective in helping students to master more vocabulary. In this present research, the significant difference of the students' score in the pre-test and posttest shows positive changes in the students' vocabulary mastery through make a match. 


\section{CONCLUSION}

Based on the data analysis and the discussion, it was found out that the t-test was higher than the t-table $(19.282>2.045)$. This indicated that the null hypothesis ( $\mathrm{H} 0)$ was rejected and the alternative hypothesis (Ha) was accepted. In short, make a match technique was effective in teaching vocabulary improving the students' vocabulary mastery of the seventh grade of Sma muhammadiyah 2 Medan in the school year 2015-2016. Thus, foreign language teachers should consider this technique as an alternative technique in teaching English.

The result of this research shows that make a match is a good vocabulary learning strategy. It encourages greater selfdirection for learners. Through make a match, students lead their self to a harder work finding words from the provided alphabets. They consult the teacher and dictionary, and they are even more active having discussion with their mates. Besides improving students' vocabulary mastery, it also creates fun learning for students. Thus, it is strongly suggested that teachers apply this technique to help improve students' vocabulary.

\section{REFERENCES}

[1] Arifah, M., \& Kusumarasdyati. 2013. The effectiveness of Make A Match Technique for teaching writing descriptive text to the seventh graders of SMPN 1 Karang binangun Lamongan. UNESA, 1(1), 1-8.

[2] Aqib, Z., 2013, Model-Model Media dan Strategi Pembelajaran Kontekstual, Bandung: Yrama Widya.

[3] Ary, Donald. 2010. Introduction to Research Education. Belmont: Wadsworth Cengage Learning.

[4] Curran, Lorna. 1994. Metode Pembelajaran Make a Match. Jakarta: Pustaka Belajar

[5] Dewi, M. 2014, The Impact of the Application of MakeA Match Technique Towards Students' Vocabulary Mastery: The Second International Conference on Education and Language (2nd ICEL) 2014 Bandar Lampung University (UBL), Indonesia. ISSN 2303-1417 
